\title{
Serum Osteocalcin, P1NP, Alkaline Phosphase, and CrossLaps in Humans The relationship with body mass index
}

\begin{abstract}
MARA CARSOTE ${ }^{1}$, SMARANDA ADELINA PREDA ${ }^{2}$, MIHAELA MITROI ${ }^{3}$, ADRIAN CAMEN $^{4 *}$, LUCRETIU RADU 5
${ }^{1}$ Carol Davila University of Medicine and Pharamacy \& C.I.Parhon National Institute of Endocrinology,Department of Endocrinology, Aviatorilor Av., 34-38, Bucharest, Romania

2University of Medicine and Pharmacy, Tabaci Str, 200642, Craiova, Romania

3University of Medicine and Pharmacy,Department of Otorhinolayngology, County Hospital Craiova, 2-4 Petru Rares Str., 200349,Craiova, Romania

¿University of Medicine and Pharmacy,Department of Oro-facial Surgery, County Hospital Craiova, 2-4 Petru Rares Str., 200349,Craiova, Romania

EUniversity of Medicine and Pharmacy, Department of Hygiene, CFR Hospital of Craiova, Stirbei Voda Str., 200374, Craiova, Romania

This is a clinical study on 56 subjects included in normal weight (NW) group ( $N=17)$, overweight (OW) group ( $N=19)$ and grade l obese (O) group $(N=20)$, based on BMI (BodyMass Index) values: NW group had a mean BMI of $22.2 \pm 2.14 \mathrm{~kg} / \mathrm{sqm}$, OW group had a BMl of $25.89 \pm 1.04 \mathrm{~kg} / \mathrm{sqm}$, and $O$ group had an average BMI of $32.2 \pm 2.09 \mathrm{~kg} / \mathrm{sqm}$ ( $p$-value NW-OW, NW-O, respective $O W-O$ groups was $p<0.0005$ ). The 3 groups were similar as age ( $p$-value NW-OW groups $=0.7$, between $N W$ - $O$ groups $=0.8$, respective between $\mathrm{OW}-\mathrm{O}$ group $=0.7$ ). The circulating bone formation (osteocalcin, P1NP alkaline phosphatase) and resorption profile (CrossLaps) indicated no statistical significant difference between groups while the coefficient of regression r between each biochemical bone marker and BMI in every BMI group exceeded the value of $p>0.05$. All the 3 groups had a mean value of 25 -hydroxycholecalciferol in deficiency ranges (< $30 \mathrm{ng} / \mathrm{mL}$, normal recommended values are above $30 \mathrm{ng} / \mathrm{mL}$ ) without significant differences regarding $B M I$ groups, except for obese group when compare to the other two groups. No secondary hyperparathyroidism was associated in any group despite low vitamin D levels. Based on our observation, bone turnover biochemical markers are not influenced by BMI.
\end{abstract}

Keywords: osteocalcin, P1NP, alkaline phosphatase, menopause, bone turnover marker

Skeleton is a dynamic complex organ with a permanent balance between bone formation and bone resorption [1,2]. Some pathological conditions like Paget's disease, primary and secondary osteoporosis, primary hyperparathyroidism first affect the bone turnover in different ways [3-6]. The best reflection of bone dynamics is done through biochemical bone turnover markers which are chemical products of bone cells with blood and/or urinary release thus they are easy to assess in daily practice [7]. Their chemical structure varies but most of them are related to matrix proteins like collagen in relationship with different enzymes $[8,9]$.

Recently, bone status was showed to be damaged in clinical circumstances priory unknown as negative targeting the skeleton by type 2 diabetes mellitus or obesity $[10,11]$. These conditions also affects the turnover of the bone cells thus the chemical molecules exported by them might reflect skeleton biology; moreover, the fat-derived hormones or adipokines control the bone function [10-12] . Alkaline phosphatase (AP) which is a basic phosphatase (a protein enzyme of $86 \mathrm{kD}$, containing 5 cysteines per monomer, 2 zinc atoms and 1 magnesium atom to achieve the catalytic role, usually the optimum active $\mathrm{pH}$ is alkaline), osteocalcin (OC) which is a gammacarboxyglutamic acid-containing protein (having a vitamin $\mathrm{K}$ dependent gla domains synthesis), also associating a hormone role, with non-collagenous bone origin, and P1NP (also known as total procollagen type $1 \mathrm{~N}$-terminal propeptide, with a trimeric structure and monomeric degradation currently considered the most relevant bone formation marker) represent bone formation markers [1315].

\section{Experimental part}

The aim of the study

Our aim is to introduce a study in human adults to highlight the bone turnover markers profile in relationship with body mass index (BMI) groups.

\section{Material and method}

This is a transversal non-interventional study on female subjects. The study was done between 2016 and 2018.

BMI was calculated based on weight, and height using the classical formula of weight $(\mathrm{kg}) /$ ( height) ${ }^{2}(\mathrm{sqm})$. We used the traditional groups based on BMI cut-offs: normal weight (NW) with BMI between $18.5 \mathrm{~kg} / \mathrm{sqm}$ and $24.9 \mathrm{~kg} /$ sqm, over weight (OW) group with BMI between 25 and $29.9 \mathrm{~kg} / \mathrm{sqm}$, and obesity (first grade) group (0) including patients with a BMl of $30 \mathrm{~kg} / \mathrm{sqm}$ up to $24.9 \mathrm{~kg} / \mathrm{sqm}$. Also the age of the patients at the moment of study is registered.

The assessments include venous blood bone turnover markers as following: bone formation alkaline phosphatase (colorimetric assay of VITROS type), osteocalcin (electrochemiluminescence method), PINP (ECLIA method of assessment), and bone resorption marker CrossLaps (electrochemiluminescence assay). Figure 1 introduces the biochemical markers reflecting the bone turnover metabolism which were assessed in the current study.

\footnotetext{
*email: adycamen@icloud.com
} 


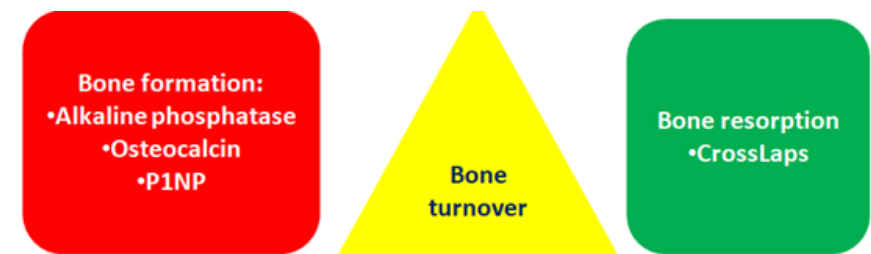

Fig. 1. Panel of investigations regarding bone turnover assessment

Also, circulating pro-hormone 25-hydroxyvitamin $D$ ( $6 R)-6-[(1 R, 3 a R, 4 E, 7 a R)-4-[(2 Z)-2-[(5 S)-5$-Hydroxy-2methylidene-cyclohexylidene] ethylidene]-7a-methyl2,3,3a,5,6,7-hexahydro-1H-inden-1-yl]-2-methyl-heptan-2ol) or 250HD was measured using chemiluminescence technique. [16] Moreover, PTH (parathormone) was also assessed (electro-chemiluminescence technique). Normal values are introduced in figure 2 .

Statistical analysis used the calculation of mean and standard deviation (SD); statistical significant was
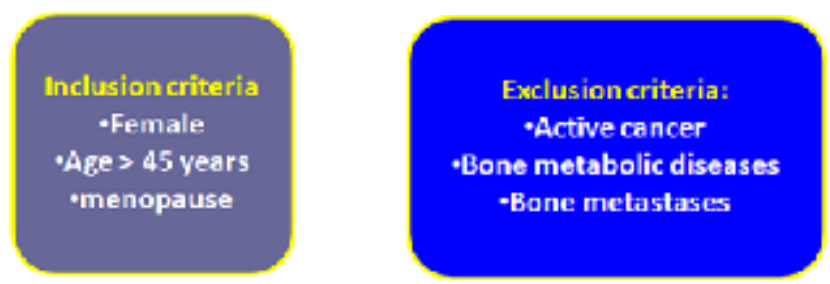

Fig. 2. Inclusion and exclusion criteria

considered at $p<0.05$ (for student ttest and linear regression).

The inclusion and exclusion criteria are introduced in figure 3.

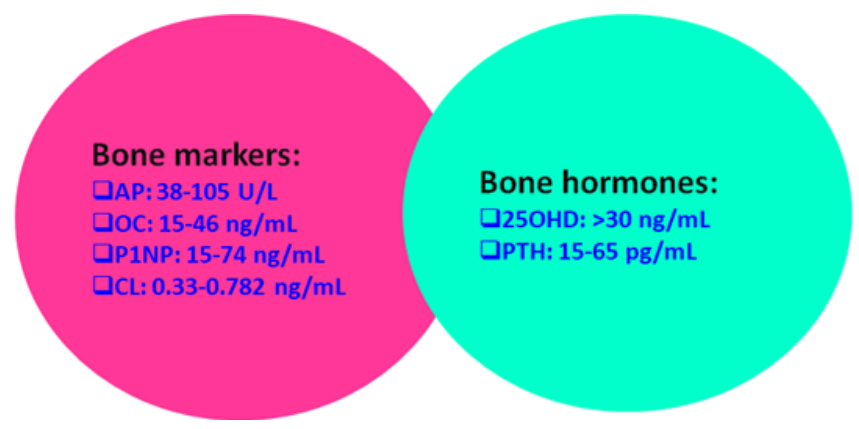

Fig. 3. Normal values of bone turnover markers and also of 25hydroxyvitamin $\mathrm{D}$ and parathormon

\section{Results and discussions}

56 subjects were included in NW group ( $N=17)$, OW group ( $N=19$ ) and $O$ group ( $N=20)$ (fig. 4) The groups were formed based on BMI values thus BMI was statistically significant different between the groups: NW group had a

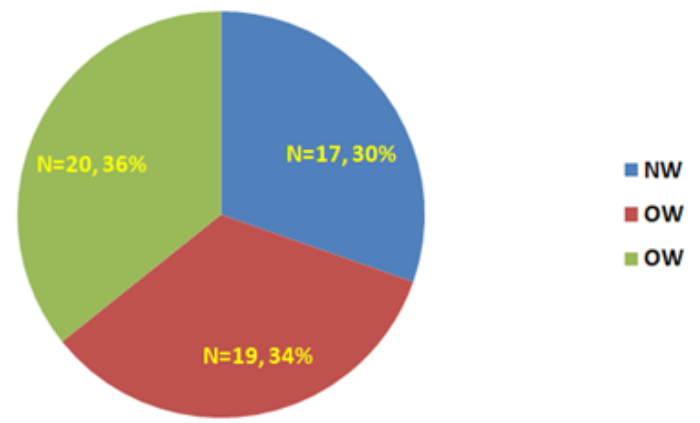

Fig. 4. The three studied groups based on BMI values (NW=normal weight, $\mathrm{OW}=$ overweight, $\mathrm{O}=$ obese)

mean BMI of $22.2 \pm 2.14 \mathrm{~kg} / \mathrm{sqm}$, OW group had a mean $\mathrm{BMI}$ of $25.89 \pm 1.04 \mathrm{~kg} / \mathrm{sqm}$, and 0 group had an average $\mathrm{BMI}$ of $32.2 \pm 2.09 \mathrm{~kg} / \mathrm{sqm}$ ( $p$-value between NW and OW, NW and 0 group, respective OW and 0 group was $p<0.0005)$. The three groups were similar as age ( $p$-value between NW and OW group was 0.7, between NW and 0 group was 0.8 , respective between $\mathrm{OW}$ and 0 group was 0.7) (table 1).

Table 1

PARAMETERS OF THE STUDIED POPULATION $(\mathrm{N}=56)$. THE PATIENTS WERE MENOPAUSAL WOMEN WHO WERE GROUPED BASED ON BMI

VALUES IN NW (NORMAL WEIGHT), OW (OVER WEIGHT), AND FEMALES WITH FIRST GRADE OF OBESITY (O GROUP)

\begin{tabular}{|c|c|c|c|}
\hline Group & $\begin{array}{c}\text { Number of } \\
\text { patients }\end{array}$ & $\begin{array}{c}\text { Age } \\
\text { (mean) } \\
\text { years }\end{array}$ & $\begin{array}{c}\text { Age } \\
\text { (SD) } \\
\text { years }\end{array}$ \\
\hline NW & 17 & 47.52 & 5.03 \\
\hline OW & 19 & 48.00 & 5.47 \\
\hline O & 20 & 47.40 & 4.51 \\
\hline
\end{tabular}

The circulating bone formation and resorption profile indicated no statistical significant difference between groups while the coefficient of regression $r$ between AP, $O C$, $P$ INP, respective $C L$ and $B M I$ in each $B M I$ group was p>0.05 (table 2).

All the three groups had a mean value of $250 \mathrm{HD}$ in deficiency ranges without significant differences regarding $\mathrm{BMI}$ groups, except for obese group when compare to te others two groups, $p=0.04$ for NW-O groups, respective $p=0.02$ for $0 W-0$ groups (table 3 ). No secondary hyperparathyroidism was associated despite low vitamin $D$ levels (table 3).

The limits of the study are the general limits of bone turnover studies meaning their high variability from one

\begin{tabular}{|c|c|c|c|c|c|c|}
\hline Group & $\begin{array}{l}\text { Number of } \\
\text { patients }\end{array}$ & $\begin{array}{c}\mathrm{AP} \\
(\mathrm{U} / \mathrm{L})\end{array}$ & $\begin{array}{c}\mathrm{OC} \\
(\mathrm{ng} / \mathrm{mL})\end{array}$ & $\begin{array}{l}\text { PINP } \\
\text { (ng/mL) }\end{array}$ & $\begin{array}{c}\mathrm{CL} \\
(\mathrm{ng} / \mathrm{mL})\end{array}$ & $\begin{array}{c}\text { Table } 2 \\
\text { BONE TURNOVER MARKERS STUDIED IN } 3\end{array}$ \\
\hline NW & 17 & $73.31 \pm 25.14$ & $29.49 \pm 11.23$ & $53.89 \pm 23.22$ & $0.55 \pm 0.19$ & \\
\hline OW & 19 & $82.35 \pm 31.11$ & $26.41 \pm 13.74$ & $63.38 \pm 45.35$ & $0.51 \pm 0.25$ & the \\
\hline 0 & 20 & $92.02 \pm 39.00$ & $23.34 \pm 12.23$ & $57.23 \pm 24.54$ & $0.44 \pm 0.23$ & \\
\hline
\end{tabular}

Table 3

BONE HORMONE VALUES IN MENOPAUSAL WOMEN WHO WERE GROUPED BASED ON THEIR BMI VALUES $(250 H D=25-H Y D R O X Y V I T A M I N ~ D, P T H=$ PARATHORMONE); THE STATISTICAL SIGNIFICANCE IS CONSIDERED AT P<0.05

\begin{tabular}{|c|c|c|c|}
\hline Group & Number of patients & 250HD $(\mathrm{ng} / \mathrm{mL})$ & PTH $(\mathrm{pg} / \mathrm{mL})$ \\
\hline NW & 17 & $23.04 \pm 11.36$ & $48.49 \pm 23.39$ \\
\hline OW & 19 & $21.43 \pm 6.96$ & $51.16 \pm 28.37$ \\
\hline O & 20 & $16.22 \pm 7.09$ & $50.19 \pm 13.24$ \\
\hline \multicolumn{4}{|c|}{ p-values } \\
\hline NW-OW groups & 0.6 & 0.7 \\
\hline NW-O groups & & 0.04 & 0.5 \\
\hline OW-O groups & & 0.02 & 0.8 \\
\hline
\end{tabular}




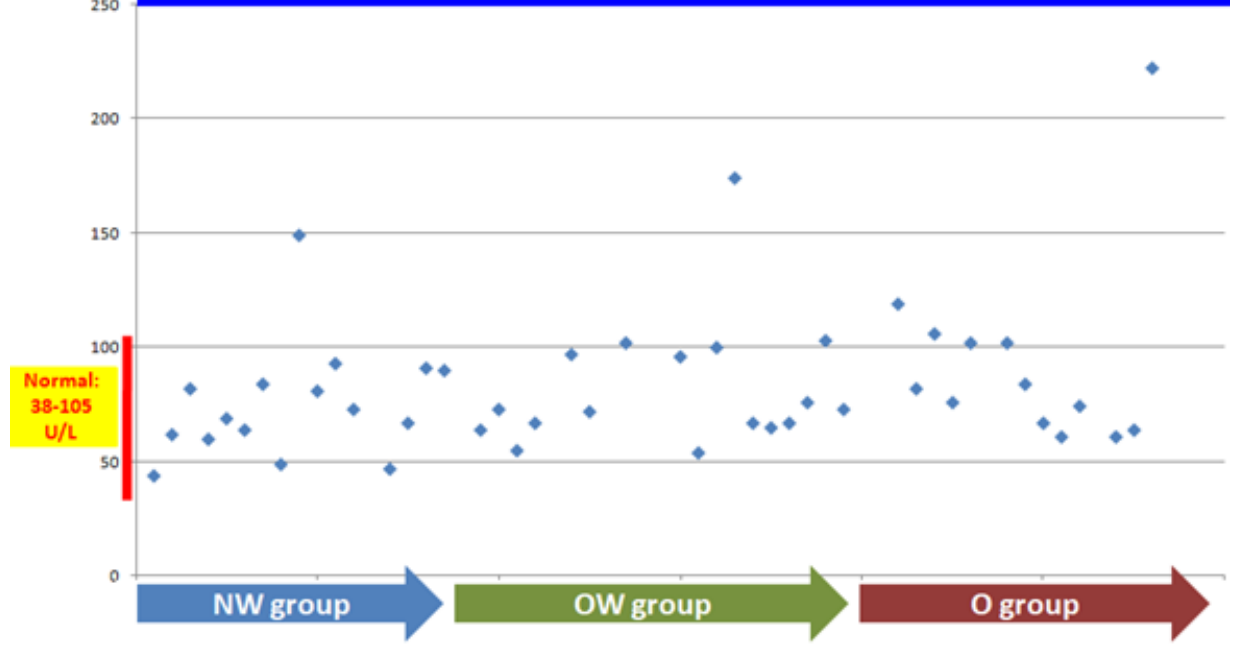

Fig. 5. The distribution of alkaline phosphatase values in menopausal groups according the baseline body mass index of each patient

Table 4

BONE RESORPTION (OR OSTEOCLASTIC OR BREAKDOWN) AND BONE FORMATION (OR OSTEOBLASTIC OR BUILDUP) MARKERS (ADAPTED FROM 17, 22, 26, 27, 28 )

\begin{tabular}{|c|l|l|c|}
\hline Bone process & Molecule & Chemical data & Abbreviation \\
\hline Resorption & C-telopeptide & $\begin{array}{l}\text { Cross linking telopeptide } \\
\text { of type I collagen }\end{array}$ & $\begin{array}{l}\text { Collagen cross-linking } \\
\text { telopeptide of type I } \\
\text { collagen }\end{array}$ \\
\hline & $\begin{array}{l}\text { Cross-links } \\
\text { Cross Laps }\end{array}$ & $\begin{array}{l}\text { Tartrate-resistant acid } \\
\text { phosphatase }\end{array}$ & TRAP \\
\hline & TRAP Hydroxyproline & OHP \\
\hline & \multicolumn{1}{|c|}{ Bone sialoprotein } & GSP \\
\hline & \multicolumn{1}{|c|}{ Gamma carboxyglutamin acid } & $\begin{array}{l}\text { Pro-collagen type I N- } \\
\text { terminal propeptide }\end{array}$ \\
\hline Formation & PlNP alkaline & AP or ALP or BSAP \\
\hline & Alkaline phosphatase & $\begin{array}{l}\text { Bone-specific } \\
\text { phosphatase }\end{array}$ & OC or S-OC \\
\hline
\end{tabular}

person to another and the need of larger population study. Moreover, we did not include all the potential categories of BMI (obesity of higher grades except first grade, also under weighted persons).

As strength of the study we mention the collateral observation regarding the high prevalence of hipoyitaminosis D in menopausal studied population.

This particular study used a combination of 4 biochemical molecules that are easy to asses in daily clinical practice through blood tests. The panel of bone turnover markers varies and their use is currently limited by a large inter- and intra-individual variation that is why a classic frame of use according to practical guidelines does not exist [17].

As mentioned in our study a large heterogeneity of the serum molecules was found (fig. 5). However, the use of chemical indices for bone metabolism is largely applied in population studies in order to point out the trend line of a particular condition or therapy regarding skeleton status, for instance, hypogonadism-related bone loss, bone metastases, primary hyperparathyroidism [18-25]. Bone formation is due to osteoblasts while bone resorption is based on osteoclasts functions [17]. Formation requires collagen I pro-peptide (P1NP) while resorption involves collagen I fragments as NTX or CTX [17]. Generally, bone collagen synthesis starts from type I pro-collagen which is later converted to type I collagen which contains a pro- collagen terminal propetide, also called P1NP (which was studied in current sample) and also type I pro-collagen Cterminal pro-peptide (also named PICP) [17].

One of the most challenging aspects in the field of bone turnover markers is the fact that many chemical products of bone cells are available and their results from studies show different results [16]. We introduced in Table 4 a glimpse of these markers indicating remodelling and demineralization.

\section{Conclusions}

Based on present study, the biochemical bone turnover markers are not distinctive between the groups of different BMI cut-offs. Large intra-individual variations do notallow a predictive model which represents one of the reason of directly applying the use of this molecules in daily practice.

\section{Abbreviations}

\footnotetext{
$\mathrm{AP}=$ Alkaline Phosphatase

$\mathrm{BMI}=$ Body Mass Index

$\mathrm{SD}=$ standard deviation

$250 \mathrm{HD}=25$-hydroxyvitamin D

$O C=$ osteocalcin

$\mathrm{CL}=$ CrossLaps

PTH = parathormone
} 


\section{References}

1.AGAS, D, LACAVA, G, SABBIETI, MG., J Cell Physiol, 2018. doi: 10.1002/jcp.26837. [Epub ahead of print]

2.LI, Q, WU, Y, KANG, N., Stem Cells Int. 2018; 2018:7098456. doi: 10.1155/2018/7098456. eCollection 2018.

3.POIANA, C, CARSOTE, M POPESCU, A, HORTOPAN, D, STANESCU, B, IOACHIM, D, Acta Endocrinologica, III, nr.1, 2007, p. 81

4.GHEMIGIAN, A, GHEMIGIAN, M, POPESCU, I, VIJA, L, PETROVA, E, DUMITRU, N, DUMITRU, I. Hormones (Athens). 12, nr. 3, 2013, p. 454-460.

5.COCOLOS, A.M., DUMITRU, N., PETROVA, E.N., COCOLOS, I., TIGLIS, M., DRAGOMIRESCU, R.F.I., OLARU, M., DUMITRU, A., GHEMIGIAN, A.M., Rev.Chim. (Bucharest), 69, no. 1, 2018, p. 134

6. RADU, L., CARSOTE, M.,PREDESCU, A.M., TENEA-COJAN, T.S.T., SOCEA, B., BALEANU, V.D., POPESCU,M., IONOVICI, N., ALBULESCU, D.M., Biochemical parameters in patients using teriparatide, Rev.Chim.(Bucharest) 69, no. 12, 2018, p. 3483 - 3485

7.HLAING, TT, COMPSTON, JE, Ann Clin Biochem,. 51, nr. Pt 2, 2014, p.189-202.

8.MIHALACHE, L., GAVRIL, R.S., ARHIRE, L.I., NITA, O., GHERASIM, A., OPRESCU, A.C., LAPUSTE, C., CONSTANTINESCU, D., PADUREANU, S.S., Rev. Chim. (Bucharest), 67, no. 12, 2016, p.2413-2416

9.EASTELL, R, PIGOTT, T, GOSSIEL, F, NAYLOR, KE, WALSH, JS, PEEL, NFA., Eur J Endocrinol., 178, nr. 1, 2018, p.R19-R31.

10.POIANA, C, RADOI, V, CARSOTE, M, BILEZEKIAN, J, Bone Research, 1, nr. 3, 2013, p. 260

11.ARBUNE, M., LUCA, M., MATEl, M.N., EARAR K., ARBUNE A., VOINESCU, D., Rev. Chim. (Bucharest ), 67, no. 2, 2016, p.320-322

12.VLADU, M., RADU,L., GIRGAVU, S.R., BALEANU, V., CLENCIU,D., ENE, C.G., SOCEA, B.,MAZEN, E., CRISTEA, O.M., MOTA, M., TENEA COJAN, T.S.,An Easy Way to Detect Cardiovascular Risk, Rev. Chim.(Bucharest) 69, no.11, 2018, p. 4229-4232

13.EASTELL, R, SZULC, P., Lancet Diabetes Endocrinol., 5, nr. 11, 2017, p.908-923.

14.*** https://en.wikipedia.org/wiki/Alkaline_phosphatase

15.*** https://en.wikipedia.org/wiki/Osteocalcin

16.*** https://en.wikipedia.org/wiki/Calcifediol
17.SONG, L., Adv Clin Chem., 82, nr. 1, 2017, p. 1-46.

18.ALBULESCU, D.M., PREDA , A.S., CAMEN, A., IONOVICI,N., Rev. Chim.(Bucharest),69, no. 7, 2018, p.1692-1694

19.POPESCU, M., CARSOTE,M., GHEMIGIAN, A., IONOVICI, N., CALBOREAN, V., DINESCU, V.C., ALBULESCU, D.M., Rev. Chim. (Bucharest), 69, no. 8, 2018, p.2089-2091

20.ALBULESCU,D.,M., CARSOTE, M., IONOVICI, N., GHEMIGIAN , A., POPESCU, M., TUCULINA ,M.J., DASCALU, I.T., PREDA, S.A., TIRCA, T., PETRESCU , M. S., BATAIOSU, M., BECHIR, E.S., Rev. Chim. (Bucharest), 69, no. 9, 2018, p.2438-2442

21.RADU, L., CARSOTE, M., GHEORGHISAN GALATEANU,A.A., PREDA,.A., CALBOREAN, V., STANESCU, R., GHEORMAN, V., ALBULESCU, D.M., Blood Parathyrin and Mineral Metabolism Dynamics - A clinical analyze, Rev. Chim. (Bucharest),69, no. 10 , 2018, p. 27542758

22. ALBULESCU, D.M., CARSOTE, M., GHEMIGIAN,A., POPESCU, M., PREDESCU A.M., TUCULINA, M.J., BUGALA, A.S., BATAIOSU,M., MARINESCU, R.I., DASCALU, I.T., STAN, M.,CUMPATA, C.N., BECHIR, E.S., Rev. Chim. (Bucharest), 69, no. 12, 2018, p. 3683-3686

23.SOCEA, B., RADU, L., CLENCIU,D., TENEA COJAN,T.S., BALEANU, V., ENE, C.G., GIRGAVU, S.R., VLADU, I.M., The Utility of Visceral Adiposity Index in Prediction of Metabolic Syndrome and Hypercholestero-lemia, Rev. Chim. (Bucharest) 69, no. 11, 2018, p. 3112-3114

24.FORTOFOIU, M., FORTOFOIU, M.C., COMANESCU, V., DOBRINESCU, A.C., PADUREANU, V., VERE, C.C., STREBA, C.T., CIUREA,P.L., Hepatocellular carcinoma and metabolic diseaseshistological perspectives from a series of 14 cases Rom. J. Morphol. Embryol., 56, 4, 2015, p. 1461-1465

25.ANDREEA-ELENA MARINAS, PAULINA CIUREA, CL. MARGARITESCU, O. S. COTOI Expression of Epidermal Growth Factor (EGF) and its receptors (EGFR1 and EGFR2) in chronic bronchitis, Rom. J. Morphol. Embryol., Vol.53, Issue 4, pg.957-966

26.***https://nos.org.uk/about-osteoporosis/diagnosing-osteoporosis/ bone-density-scanning-dxa/bone-markers-and-osteoporosis/ 27.*** http://archive.unu.edu/unupress/food2/UID06E/UID06E1B.HTM 28.*** https://biomarkerres.biomedcentral.com/articles/10.1186/ s40364-017-0097-4

$\overline{\text { Manuscript received: } 21.10 .2018}$ 